\title{
BATTLING FOR SHARED CULTURE BETWEEN INDONESIA AND MALAYSIA IN THE SOCIAL MEDIA ERA
}

\author{
Liliek Adelina Suhardjono \\ Jurusan Desain Komunikasi Visual, School of Design, BINUS University \\ Jl. K. H. Syahdan No. 9 Palmerah, Jakarta Barat 11480 \\ liliek_adelina@yahoo.com
}

\begin{abstract}
This is a research paper that takes as its central issue recent contestations and negotiations between Indonesia and Malaysia regarding certain forms of these countries' intangible cultural heritage. In recent years, there has been an increasing incident in relation with cultural conflicts that happens between these two neighboring countries. These cultural conflicts specifically referred to the traditional performance arts, which has been hereditarily bequeathed by their respective ancestors. Despite the facts that both countries shared the same cultural roots, each side seems has a tendency to despise each other whenever the subject of culture ownership is being brought: both claim for the same cultural rights. Questions on which side is more entitled to the rights became public fierce debates; and it wildly happened especially in the online world through the medium of social networking platform. This paper examines the phenomenon on how should the ownership of authenticity be placed. And since it happens in the modern societies which cannot be separated from their digital personas, the role of social media is inexorably also be addressed. It will link the two identities of the public who is initially mere the audience of the performance then transform into the owner of the cultural product in dispute. This essay begins by a major length discussion about the concept of authenticity in culture, along with the ownership of intangible heritage, the motivation for claiming authenticity, and the protection of cultural property. It will then go on to the topic of the major changes brought by social media in the modern society. Subsequently it will continue to the state of cultural conflict between Indonesia and Malaysia over 'stolen' cultural heritage.
\end{abstract}

Keywords: shared culture, intangible cultural heritage, cultural ownership, authenticity in culture, social media

\begin{abstract}
ABSTRAK
Ini merupakan sebuah makalah penelitian tentang perselisihan dan negosiasi antara Indonesia dan Malaysia tentang bentuk tertentu dari warisan budaya tak berwujud. Beberapa tahun terakhir, telah terjadi insiden meningkat sehubungan dengan konflik budaya yang terjadi antara kedua negara tetangga ini. Konflik budaya secara khusus mengacu pada seni pertunjukan tradisional, yang telah turun temurun diwariskan oleh nenek moyang masing-masing. Meskipun fakta bahwa kedua negara berbagi akar budaya yang sama, masingmasing pihak tampaknya memiliki kecenderungan untuk membenci satu sama lain setiap kali subjek kepemilikan budaya yang dibawa: baik klaim untuk hak budaya yang sama. Pertanyaan pada sisi mana yang lebih berhak menjadi perdebatan sengit publik, dan hal itu liar terjadi terutama di dunia online melalui platform media jejaring sosial. Makalah ini membahas fenomena tentang bagaimana seharusnya kepemilikan keaslian ditempatkan. Dan karena itu terjadi dalam masyarakat modern yang tidak dapat dipisahkan dari persona digital mereka, peran media sosial tak terelakkan. Hal ini menghubungkan dua identitas masyarakat yang awalnya sekadar sebagai penonton kemudian berubah menjadi pemilik produk budaya yang berselisih. Esai ini dimulai dengan diskusi panjang utama tentang konsep keaslian dalam budaya, bersama dengan kepemilikan warisan budaya tak berwujud, motivasi untuk mengklaim keaslian, dan perlindungan atas kekayaan budaya. Kemudian dilanjutkan ke topik perubahan besar yang dibawa oleh media sosial dalam masyarakat modern. Selanjutnya, dilanjutkan dengan konflik pencurian warisan budaya Indonesia oleh Malaysia.
\end{abstract}

Kata kunci: budaya bersama, warisan budaya tak berwujud, kepemilikan budaya, keaslian budaya, sosial media 


\section{INTRODUCTION}

Cultural conflicts with the subject of traditional performances between Indonesia and Malaysia are largely known by the public based upon media discourses. In recent years, there has been an increasing amount of technological advances in media development. Digital media and social networking play important roles on magnifying the scale of the controversies. This chapter provides an overview of the theoretical background of the chosen topic.

According to Jones, Anand and Alvarez, all works in the scope of cultural domain, in its own way has always been wrapped up with claims to authenticity (2005: 893). But what has most often been happened is that people take the claim of their cultural property for granted. They do not give a proper attention and tend to forget its value, until some other party claims those properties. And when it happens, the seeds of predicament are being born. Peterson (2005: 1083) suggests that the issue of authenticity commonly grows when authenticity has been put in uncertain situation. This is exactly what has been happened between the two countries, Indonesia and Malaysia, since both of them persisted in their own opinion, which naturally put them on a state of doubt.

In a sense, intangible heritage culture is vulnerable since it embodies intangible ideas, therefore often times become an object of copying or unauthorized reproduction (Scafidi 2005: 13). Intellectual property, according to Oxford Dictionary Online is an intangible property that is the result of creativity, such as patents, copyrights, etc. To be able to obtain an incentive so that authors and inventors can continue their creativity is the purpose of legal protections, it makes a way for them to seize the commercial value of their works (Scafidi 2005:14).

There are number of other motivation when people claiming authenticity: economical reason, self-fulfillment, and law-related reason. In this global commercial era, having a unique character that is considered to be 'traditional' especially when the product is belong to one and only place surely not hurt at all, it definitely can be packaged for the sake of the tourist industry (Peterson 2005: 1084). John Dewey suggests that workplace is a good place to observe the motivation for authenticity, since workers tend to find fulfillment on their works, and to be able to find such a releasing channel is itself satisfactory. He then continues to clarify that in accordance with reality where the motivation is put upon financial gain, it will shear away the pure gratification from the person who originated the work (qtd.in Vaninni and Burgess 2009: 107). While Patry verifies in his book that that policymakers generally say that copyright law should contribute incentives for the authors, provide community who wants to access the works, and bestow respect by virtue non-economic rights for the creator of the cultural pieces (2011: 75). Cases that is brought in this paper has almost all those motivations, but with the emphasize on the respect value as a nation who wants to protect tradition as a heritage of their ancestors.

The issue of culture authenticity became a great subject of public debates, more or less cannot be separated from the role of social media. Instead of being passive and waiting for the latest development of the culture conflict, Indonesian and Malaysian people can virtually form groups, voice their opinions directly to each other, having an online cultural war, with people from all over the world as their audience, passive or active since everyone regardless their nationality can also contribute to this very matter of subject.

\section{RESEARCH METHODS}

This essay has been conducted through two ways. The literature observation mostly used on the attempt to find a theoretical background, consists of books, journal, articles, both online and printed version. Meanwhile on the effort of finding data surrounding the case study, websites, blogs and forums, articles and comments are mainly used. 


\section{Case Study: Cultural Conflict between Indonesia and Malaysia over 'Stolen' Cultural Heritage}

Asia is said to be a region with a higher degree prone to conflicts, and most of it happens domestically surrounding the issue of religion, identity and historicity conflicts (Croissant and Trinn 2009). In the Indian documentary In The Name of God (Ram Ke Naam) by Patwardhan (1991) we can see how Asian people are easily triggered into a conflict when their religion and identity is being disturbed. Meanwhile in the Southeast Asia where Indonesia and Malaysia are both located, the statistic suggests that the cultural dispute is mainly gravitating toward the issue of historicity (Croissant and Trinn 2009).

\section{Cultural History background of Indonesia and Malaysia}

Indonesia and Malaysia are two neighboring countries, geographically located in Southeast Asia. As we can see in the map below, this region consists of many islands, big and small. In fact there are thousands of islands in total, and together they are called Nusantara. History tells that the word Nusantara was said back then in the year 1336, in an oath by Gajahmada, a military leader of Majapahit Empire. In his oath he determined to conquer the whole archipelago under the authority Majapahit. When the colonialism took a power in this region, the archipelago is divided into a few smaller regions, which is then grow into a different nations named Indonesia, Malaysia, Singapore, Brunei and the Philippines.

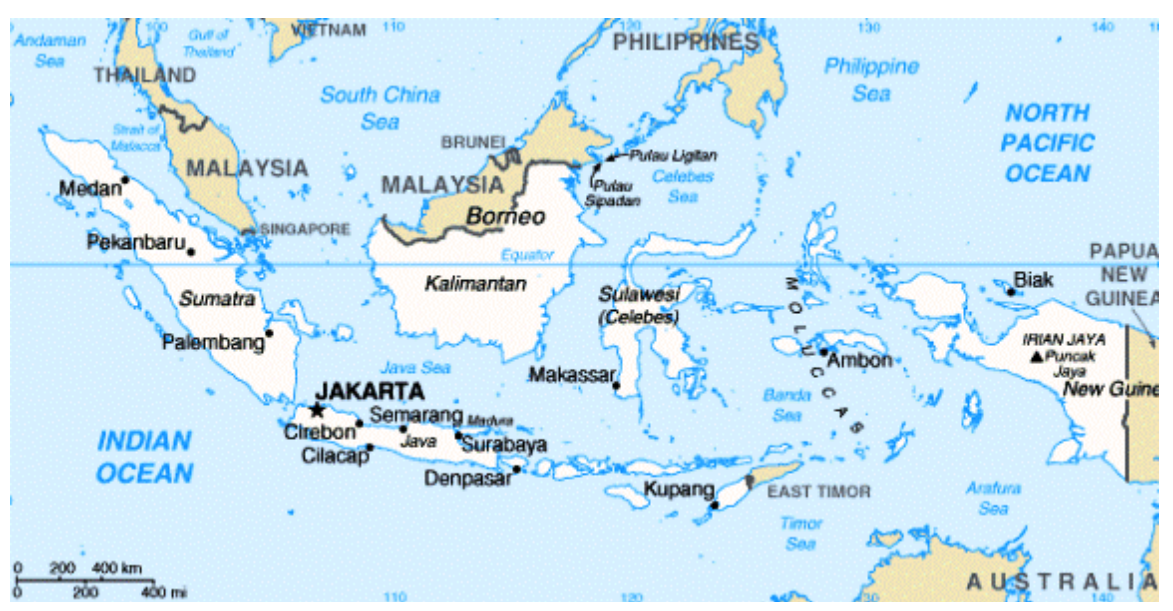

Figure 1 The map of Indonesia \& Malaysia.

Web accessed 8 January 2012

(waronterrornews.com/indonesia_malaysia.html)

Today, in Indonesia the word Nusantara has the meaning of national territory of Indonesia. While in Malaysian term, the same word means the whole original territory including Malaysia, Singapore, Brunei and the Philippines.

Because of its geographical location, Professor Ghulam-Sarwar Yousof (2009), a specialist of traditional Southeast Asian theatre explains in his article that Malaysia has shared and borrowed their demographic make-up and cultural history from Indonesia as well as other cultures. He pointed out that this sharing and borrowing action naturally happen and is easily being seen in the Sabah and Sarawak region, which are located in the north part of Borneo island of Indonesia. So even though 
political borders are clearly drawn between the two, it is not necessary coexist with cultural realities that socially happen among the citizens.

\section{The Conflict between Two Countries}

Regardless the acknowledgement that these two countries shared the same cultural roots, each nation seems to disdain one another whenever the subject of culture ownership is being brought. It is very easy to understand how both side ended to claim for the same rights of cultural ownership. Now the question is, which side is more entitled to the rights? One has to carefully putting boundaries in answering this question, is it ethically, politically, economically, or legally?

According to Halbwachs and Coser (1992: 53), everyone has a different capability to reserve a memory, and this each and every personal memory is nonetheless a part of a group memory, which is why they used the term 'collective memory', in exploring the reinterpretation of past people or events to harmonise them with current political needs and cultural understandings. If we make an assumption based on the collective memory, then everyone can assert ownership of intangible heritage culture, because the ground is abstract, there are no material proofs. As long as there is a society agrees to have one voice, they are able to claim a certain intangible heritage culture. This ambiguity happens over and over again in all cases of cultural dispute between Indonesia and Malaysia; either in traditional song, dance or performance.

\section{The Cultural Heritage as the Source of Conflict}

Here are some of the traditional performances that have became sources of cultural conflict between Indonesia and Malaysia.

\section{Reog Ponorogo Performance}

Reog Ponorogo is a dance performance, which demonstrates physical strength and extravagant lion-peafowl mask and costumes. While Reog dance itself originally comes from Java island in Indonesia, this dance also spread in Malaysia, namely in Johor region. The reason is because there are numerous descendants of Javanese immigrants; whose brought Javanese culture along with their migration (Prathivi 2009). In their new homeland, with the collective memory on works, they continue to practice the arts, and even consider it as their occupation. A simple gesture that did not hurt anyone.



Figure 2 Reog Ponorogo performance

Web accessed 5 January 2012.

(folktales.checkitouts.info/east-java/reog-ponorogo/) 
The controversy started to sparked after Malaysia tried to claim the dance, under the name of Barongan Dance. This act angered Indonesian public. After some turmoil between two countries, Malaysia decided to stop to promote the dance, to avoid further quarrel (Majid 2007). This aftermath directly affect the Malaysian community who perform the dance, they literally lost their source of livelihood. This development have a negative impact for both countries, Malaysian has no longer can performed this dance and Indonesian lost its tools of promoting its art to their neighbor, and in longer term will decline the growth of the performance itself.

\section{Pendet Dance}

Pendet is a traditional dance from Bali Island, Indonesia. This dance classically performed by young girls, with offerings to purify the temple or theatre as a welcome greetings, prelude to ceremonies or other dances.

In 2009, Discovery TV network launched a commercial in Singapore with the title Enigmatic Malaysia, featured Pendet dance, which was mistakenly seen as Malaysian dance. As expected, this commercial angered millions of Indonesian. Having realised this unexpected outcome, Malaysian government then apologised. But the Indonesian counterpart was quickly rejecting this apology, because it was done only via telephone, which was considered to be informal. Indonesian Tourism Minister demand an official letter of apology, but this demand is declined by the Malaysian, since they did not feel responsible for a commercial that was not an official product of Malaysia (Sagita 2009). Later the television network who produced the commercial removed the advertisement and delivered a formal apologies to both nations, but the damage has been done (Karana, Prameshwari 2009).

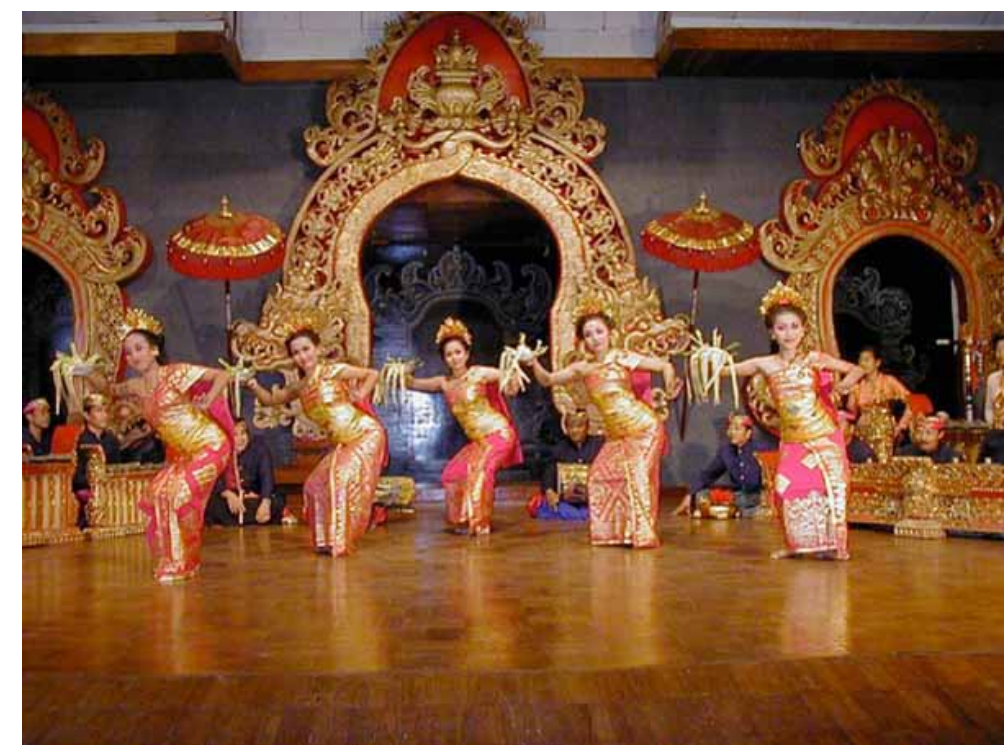

Figure 3 Pendet Dance. Web accessed 5 January 2012

(the-indonesian-cultures.blogspot.com/2010/09/tari-pendet-pendet-dance.html)

Although a set of other motivation can be mentioned, here we can see the economical motivation works at its best. The use of the Pendet dance in this commercial is no longer to be a welcome greetings but to generate tourism to a certain country, which in the end will generate a foreign exchange. Moreover this commercial itself is made by a TV network, which basically performed a tendency to treat the dance as a mere commodity. 


\section{The 'Rasa Sayang Hey’ or 'Rasa Sayange’ folk song}

This folk song Rasa Sayang Hey (song title according to Malaysia) or Rasa Sayange (Indonesian version title), is another source of dispute between the two. It is ironic since Rasa Sayange literally means 'the feeling of affection', and its lyrics voice a loving feeling towards life surrounding. As a matter of fact, this song is also popular in Singapore, but they are not included in the dispute since they have never tried to make a claim over this song.

Indonesian believed that the song is originally come from Mollucas, a part of Indonesian region. On the other hand, Malaysian argued that the song is a product of Nusantara, which mean according to their definition of Nusantara (see above information), the song is a common property of all Nusantara countries, including Malaysia.

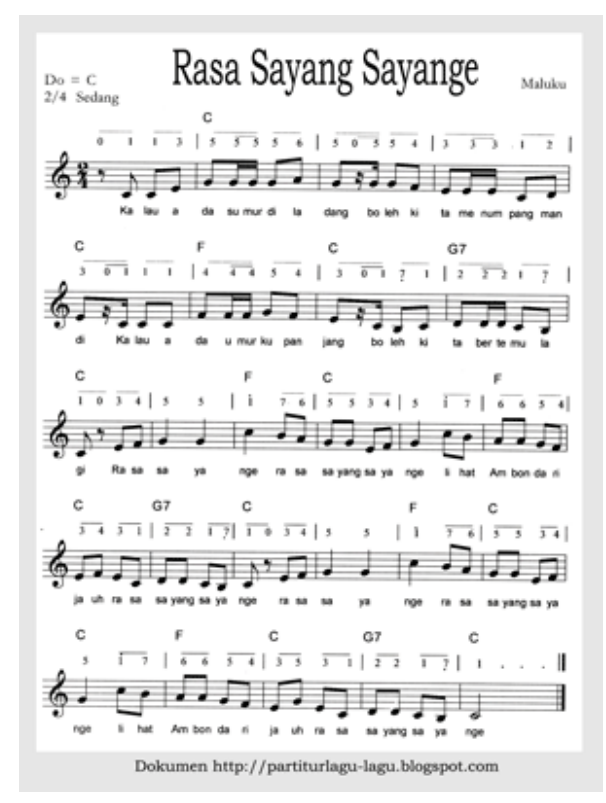

Figure 4 The song Rasa Sayange Partiture. Web accessed 5 January 2012.

(partiturlagu-lagu.blogspot.com/2010/01/lagu-daerah-maluku-rasa-sayang-sayange.html)

\section{Angklung or Bamboo Malay musical instrument}

Angklung is a musical instrument made of two bamboo tubes attached to a bamboo frame. The tubes are carved to have a resonant pitch when struck and are tuned to octaves. According to the Indonesian historical record angklung has been played for a long time in Indonesia, particularly in Java and Bali. In Malaysia, angklung is known as bamboo malay. Malaysian tried to claim bamboo malay because they believed it has a different characteristic with angklung, since it has diatonic arrangement, whereas Indonesian angklung has the arrangement of five-tone tone (pentatonic).

In November 2007, Indonesia and Malaysia hold a friendship gathering in Kuala Lumpur Convention Center in Malaysia. In that occasion Ika Widyaningsih, an Indonesian angklung artist taught the audience who are mostly Malaysian citizen on how to play angklung. From Indonesian perspective, this cultural mission has a double meaning. One to spread the popularity of angklung, but at the same time this is also a gentle innuendo to the Malaysian, to keep their ethic in order to maintain the friendship of the two neighboring countries (Hamonangan 2007). 
Later on Indonesian government then registered the instrument and in the year 2010 UNESCO listed angklung as Indonesian intangible cultural heritage (UNESCO 2010).

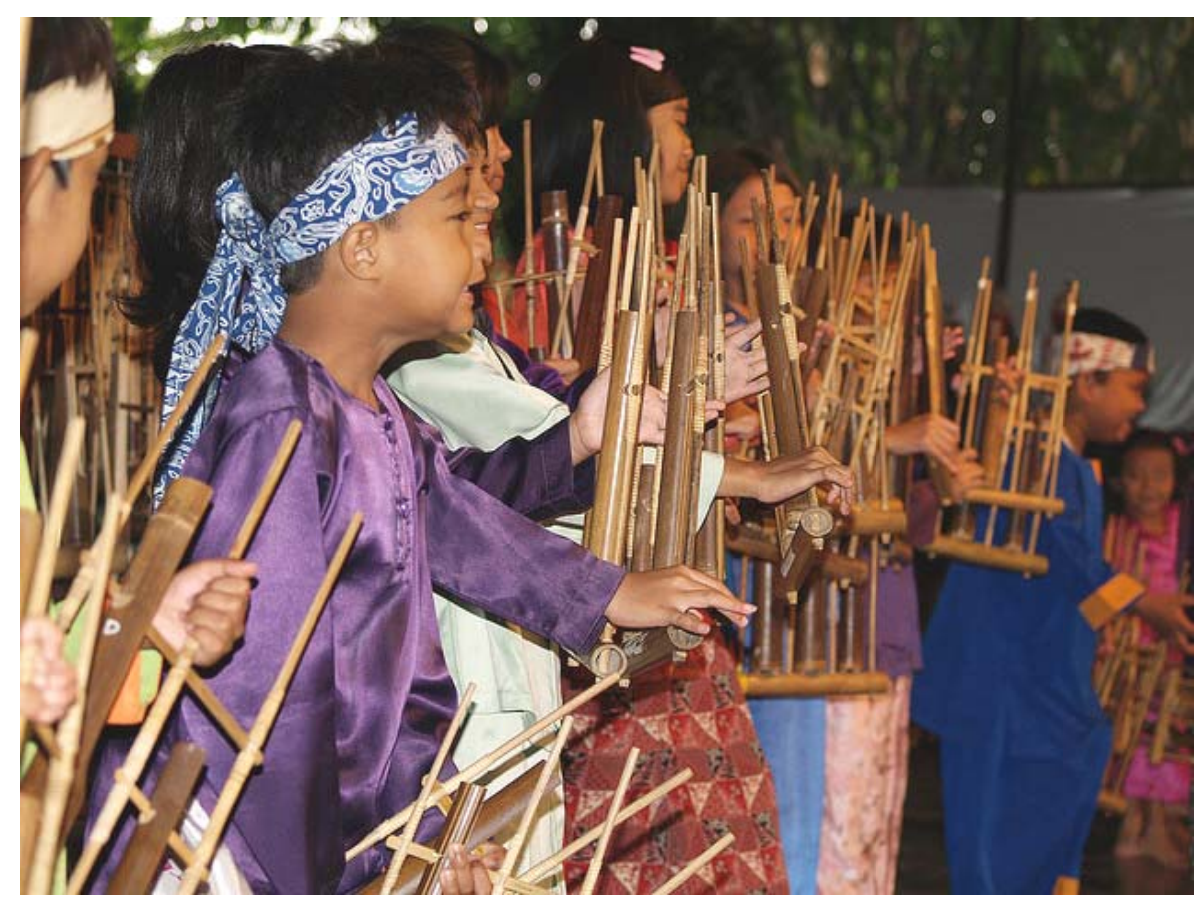

Figure 5 Angklung. Web accessed 5 January 2012

(traditionalmusicinstrument.blogspot.com/2011/07/how-to-to-playing-angklung-part-1.html)

\section{How Indonesia and Malaysia perceive the conflict respectively}

What we see in the surface is not always represent of what is actually happen in reality. Under the pressure to preserve a good manner and behave in a ethical way, whenever people from both countries meet each other in real life, they will act accordingly, with the politeness and courteous manner as how eastern culture expected to be conducted. However, under the masking shadow of digital world, they speak freely, mocking each other blatantly, sometimes even using the words of profanity. Social media has once again reveal to the world the real conduct of human behavior when presented with a very limit restriction. Physical war may not happen in the reality, but this shared culture conflict has become a heated battle in the online world.

Through each and every case study, we can draw a conclusion, that Indonesian people are somewhat ignorant at the beginning. They always shocked whenever new claim of their intangible cultural heritage happens. Hamdani (2009) analyses that they are panicked over the threat of losing the status 'owner' of the heritage into the so-called 'illegitimate heirs', and this hysteria sometimes metastasized into an overreacted conduct, such as demanded the end of diplomatic relations with Malaysia, repeating an old concept of the Ganyang Malaysia confrontation, which was happened back on 1963.

Advertising industry was not to be left and plunged itself into the middle of the chaos. For example 'Tolak Angin', a prominent jamu (herbal medicine) brand, made a bold move by producing its commercial based on the concept of exhibiting the nation's pride over its cultural heritage, namely the traditional performances that has been mentioned before: Reog Ponorogo, Angklung, Pendet Dance, and some other cultural heritage including the jamu itself. This commercial using the melody tone 
from the folk song Rasa Sayange, and even mocking Malaysia by openly claiming that all those cultural heritages are 'Truly Indonesia'. For those who doesn't familiar with this line, Malaysia's tagline for its tourism campaign is 'Malaysia, Truly Asia.' Besides being broadcasted by Indonesian television channel, this commercial was also widely spread through video-sharing website, YouTube. It is easy to imagine how obnoxious the war arguments in the video's comment section.

Malaysia in more than one occasion, if not always, is the one who started the conflict with make the first move of claiming the rights towards the shared intangible heritage culture. It shows that Malaysia somewhat have a higher knowledge regarding the importance of copyrights for culture product. Of course it is not a question that Malaysia feel they historically is the legitimate owner of those culture product, but based on Azahari's comment (2008) on the one of the online forum, that what has been done by Malaysia is probably a reflection of their inferiority complex, because as a nation Malaysia only has a small number of original heritage culture, compared to their neighbor. So with their awareness of culture rights they try to claim whatever culture can be traced back to their history. Of course the legitimation of his comment is highly dubious, but this is an honest opinion from a Malaysian itself.

Richard Gough (2009: 31) questions in his case study of troubling performance, is the act of embracing another culture by doing what they do, such as dance the dance, the form, is in any way could make them closer to that tradition? Applying his question into the topic of this very essay; when the roots of the tradition is unquestionably can be traced with the present history, is it possible that the act of performing tradition automatically become a validation of claiming the authenticity? Gough offers a further argument based on his observation on how theatre histories repeatedly prove that one advanced trailblazing set of theatre practice has becoming an inspirational guidance on the theatre culture of another nation. It brings him to the new concern, when all these concoctions of old and new materials are mixed together and started to take over the scene, where does that leave the traditional native culture? But finally he draws a conclusion that nothing can vanquish the genuineness of experiencing an authentic performance in a place where it was once originated, at the very beginning (2009: 31). In simple sentence, when searching for authenticity, the best place to experience traditional performance from Malaysia is in Malaysia and the most authentic place to experience Indonesian performance is none other than in Indonesia.

\section{Questioning the act of claiming an ownership}

If we see this case from a slightly different perspective, we can also questions, does the act of building a culture embarked from another culture is always has a counterfeit result? Take an example of the history of graphic design/visual communication design as an academic discipline in Indonesia. As a relatively new discipline that is right now still in the period of to gaining its popularity, Indonesian scholars in this field build the academic foundation based on the theories and art history from the western's timeline. From Arts \& Crafts movement, Renaissance, Baroque, Art Nouveau, Art Deco, Swiss Style, and so on and so forth until designs from the current time, all is in direct reference to the west. Logically, when the seeds are originated from the west, later on it will give birth to a western flower. But with the help of some local fertilizers it turns out that the original ecosystem is now changed and the results is the blooming of a new hybrid flower, with the smell of local culture. This pattern of combining two different elements to produce a new culture (whether it is tangible or intangible) can be a solution for the question of ownership.

Even when the question of ownership has been answered, there are still a big question mark left, on what certain degree a nation should protect its cultural property. How can we decide that one object is considered precious enough to be copyrighted? What differentiate one object to the other in term of its worthiness, since culture is continue revolving and perception can be changed from time to time. While one cannot deny the fact that that we must promote the action of protecting cultural properties, there is on the other hand, a different strong opinion against the act of copyright, as it is 
feared that legal limitation would hamper the expansion of creativity. The lack of protection on the cultural property. In one of his article, Patry (2011: 95). stated that to oppose one's potential to copy is the same with denying one's aspiration of becoming who they desire to be. He continue that based on his observation on the history of the human mankind, Patry believe that on some level, copying is the first step of creating a new works, whether it is a painting, a book, a performance or many other things. This is actually make sense, because in reality, when someone want to mastering some skills, first he needs to have a clear goal of his vision, which is none other than previous results of other people's creation. For example if we want to create a painting, we will first need to know the basic skills of painting, the colours, the perspective, the composition, and many other painting principals; and the most effective way to learn this skill is by copying a good paint on the first place. In some fields such as advertising industry, it is almost inevitable to create something absolutely new from the scratch. It is not because people in that field lacking creativity, on the contrary they are supposed to be a creativity generators. But too many ideas have been done while their task, which is basically to make a successful commercial, is never change. That's why the real challenge is how to pick old ideas, tweak them, recycle them, do anything on them and create something new out of it. It is all possible to be done if people have the rights to copy at the first place.

\section{The role/influence of social media regarding the conflict}

Oxford Dictionary Online define that social media is websites and applications used for social networking such as blog, online forum, networking sites such as Facebook, Twitter, LinkedIn. Through social media people can virtually meet each other and formed an online community based on the same interest, political views, religion, nationhood, and many more. They also can interact one to another, buying and selling stuff, announce a cause, and almost practically everything else people do in real life, there they can find its similar substitute.

Since it was first invented, the World Wide Web has forever changed the life of human being. Slowly from being used for work purpose, it is now taking over the human life itself. Not exaggerating, seeing that so many people are now spending most of their time in front of computer, having second identity in a digital world, not necessarily in the sense of fake identity but their presence in the virtual world itself is creating a new persona. People have the authority to choose who he wanted to be, he can be A, he can be B, he can even be the entire alphabet.

Through digital world we can grab all the latest development in the whole universe, only by nicely sitting in front of our computer, in one condition: it is connected online. Qualman (2009: 11) observes that these days, people no longer chasing for the news, rather the news hunts us. He added that we have shifted from a condition where a number of information source distributed to the bulk of population, into a world where millions individual sharing and distributed news to their selected environment.

\section{Social media as vehicle to generate nationalism}

Since in the real world one nation can be tremendously vast, if it is not because of those online community people would otherwise never met one to another. In the digital world, the geographical aspect doesn't play an important role. People from many parts of the world whose identifying themselves as a member of a nation can combine the force, creating a whole new level of nationalism.

On a positive side, social media generates nationalism from the public and grows their sense of belonging, which on this subject is the heritage culture itself. From just a mere audience now they labeled themselves as the owner of the culture. Both countries build their own community based on the notion of belonging and feeling to defend the pride of their respective nation. This nationalism aspect clan be clearly seen for example in the Twitter and Foursquare generated campaign for commemorating Indonesian independence day, by having an online flag ceremony. This online 
community movement firstly held in the year 2010. If using conventional media people just acting as the receiver of the news, now they can contribute to the discussions, voice their opinion, argue against their counterpart and so on.

However on the negative influences, it did spread hatred and anger between two countries. The anonymity element of the virtual world plays a significant role in raising the heat of the conflict. The lack of responsibilities mainly because the anonymity factor is cannot be escaped. There is also a danger from the existence of people/party who pit against each other. That is why, no matter how hard it is, clear mind and self control needs to be maintain at all time.

\section{CONCLUSION}

In conclusion, there are a number of reasons why the phenomenon of battling for shared culture happened between Indonesia and Malaysia. Here we can see that authenticity holds an important role in order to get a recognition as the owner of the culture in dispute. But most of the time it is a difficult to judge which side is more deserve to get the rights. The fact that this conflict happened in digital era also bring some more dimension into the direction of the conflict went. Indeed as Charles Caleb Colton said in his famous quote, 'imitation is the sincerest form of flattery'; making a copyright of other's culture or even culture which still on the realm of ambiguity, on the other hand is totally a different action. All this conflicts made people from both countries realised the importance of keeping their cultural heritage. They change their attitude by never again take their culture for granted. It's a hard way to learn, but the fruit will come up later in the future. Although it has been carefully edited, in the end this essay is still a writing made by Indonesian writer. Having a personal subjectivity and patriotic feeling, bias standpoint is inevitably happen here and there.

The focus of the achievement whenever a country getting a legal rights upon their intangible heritage culture should not be on the 'winning' fact. It is not a battle to prove who's superior against the other. Instead we need to concentrate on how to promote the culture itself. On the subject of racy comments on the internet, people really need to restraint themselves and not to easily insulted or angry upon trivial things. Start learning to have priorities in what is important, and use the best of the time with it. Equally important are the effort to create a new culture based on existing culture, using many direction: mashing up several components, combining traditional element with a new features, taking the whole textures of the old tradition as the pattern and from there create a new art which exhale the same air with its predecessor. Meanwhile never forget to preserve the old one, providing it is our duty to pass it to our children.

\section{REFERENCES}

Anderson, E. (2010). Social Media Marketing: Game Theory and the Emergence of Collaboration. Heidelberg: Springer. Print.

Azahari. 'Memahami Sikap Malaysia.' Weblog comment. Kompas Forum. Kompas, 9 Oct. 2008. Web. 8 Jan. 2012. <http://forum.kompas.com/internasional/811-situs-malaysia-sangatmelecehkan-bangsa-indonesia-15.html $>$.

Croissant, A., and Trinn, C. 'Culture, Identity and Conflict in Asia and Southeast Asia.' ASIEN 110.January (2009): 13-43. Web. 05 Jan. 2012. http://www.uniheidelberg.de/politikwissenschaften/personal/croissant/publikationen_en.html 
Gough, R. (2009). 'Troubling Performance: Local, National and International.' Mapping Landscapes for Performance as Research: Scholarly Acts and Creative Cartographies. By Shannon Rose. Riley and Lynette Hunter. Basingstoke: Palgrave Macmillan. Print.

Halbwachs, M., and Coser, L. A. (1992). On Collective Memory. Chicago: University of Chicago.

Hamdani, D. 'Battling for Shared Cultures.' The Jakarta Post. PT Bina Media Tenggara, 14 Sept. 2009. Web. 01 Dec. 2011. <http://www.thejakartapost.com/news/2009/09/14/battling-sharedcultures.html>.

Hamonangan, Agus. "Jangan Ambil Angklung Kami, Pakcik!" Forum Pembaca KOMPAS. 13 Nov. 2007. Web. 28 Jan. 2012. <http://www.mail-archive.com/forum-pembacakompas@yahoogroups.com/msg25035.html>.

Jones, Candace, N. Anand, and Josè Luis Alvarez. 'Manufactured Authenticity and Creative Voice in Cultural Industries.’ Journal of Management Studies 42.5 (2005): 893-99. Web. 30 Nov. 2011.

Karana, Kinanti P., and Putri Prameshwari. 'Outrage Over 'Stolen' Pendet Dance Ends Up As a Misstep.’ The Jakarta Globe. Berita Satu Media Holdings, 25 Aug. 2009. Web. 01 Dec. 2011. $<$ http://www.thejakartaglobe.com/home/malaysia-not-trying-to-steal-pendet-says-indonesianembassy/325729>.

Majid, N. A. 'Persembahan Barongan Tidak Wajar Dihentikan.' Utusan Malaysia Online. 6 Dec.2007. Web. $<$ http://www.utusan.com.my/utusan/info.asp?y=2007\&dt=1206\&pub=Utusan_Malaysia\&sec= Muka_Hadapan\&pg=mh_08.htm>.

Oxford Dictionaries Online. http://www.oxforddictionaries.com/

Patry, W. F. (2011). How to Fix Copyright. Oxford: Oxford UP.

Patwardhan, A. (1991). In The Name of God (Ram Ke Naam). DVD.

Peterson, R. A. 'In Search of Authenticity.' Journal of Management Studies 42.5 (2005): 1083-098. Web. 29 Nov. 2011.

Prathivi, Niken, and Irawaty Wardany. 'Protests over Presence of Pendet Dance in Malaysia’s Tourism Ad Continue.' The Jakarta Post. PT Bina Media Tenggara, 23 Aug. 2009. Web. 30 Nov. 2011. <http://www.thejakartapost.com/news/2009/08/23/protests-over-presence-pendet-dancemalaysia\%E2\%80\%99s-tourism-ad-continue.html>

Qualman, E. (2009). Socialnomics: How Social Media Transforms the Way We Live and Do Business. Hoboken, NJ: John Wiley \& Sons. Print.

Sagita, D. 'Indonesian Minister Rejects Malaysian Pendet Apology.' The Jakarta Globe. Berita Satu Media Holdings, 28 Aug. 2009. Web. 14 Jan. 2012. $<$ http://www.thejakartaglobe.com/national/indonesian-minister-rejects-malaysian-pendetapology/326562>.

Scafidi, S. Who Owns Culture?: Appropriation and Authenticity in American Law. New Brunswick, NJ: Rutgers UP, 2005. Print.

UNESCO. Culture. Indonesian Angklung. UNESCO. Government of Spain, 2010. Web. 9 Jan. 2012. $<$ http://www.unesco.org/culture/ich/en/RL/00393>. 
Vannini, P., and Sarah Burgess. 'Authenticity as Motivation and Aesthetic Experience.' Authenticity in Culture, Self, and Society. By Phillip Vannini and J. Patrick Williams. Farnham, England: Ashgate Pub., 2009. Print.

Yousof, G. S. 'On the Current Malaysian-Indonesian Conflict on Cultural Forms.' Ione Traveller. 3 Aug. 2009. Web. 25 Nov. 2011. <http://gsyousof.blogspot.com/2009/09/on-currentmalaysian-indonesian.html>. 